\title{
KINO I TELEWIZJA - ZAGROŻENIA I SPOSOBY PRZECIWDZIAŁANIA NADMIERNEMU WPŁYWOWI STANÓW ZJEDNOCZONYCH W EUROPIE
}

\author{
Abstract \\ CINEMA AND TELEVISION - THREATS AND WAYS OF COUNTERACTING \\ THE INFLUENCE OF UNITED STATES IN EUROPE
}

The subject matter of the article is cinema and television in Europe, and more precisely the influence of the United States on their development and the way of counteracting this domination. The reason for the interests presented in the text is the conviction of the important role of the film in the life of every human community. The article answers the question of whether Europe is only a profitable market for American corporations and it draws attention to the fact that media history in the world is a history of mutual relations between American and European media. The growing importance of the United States in relation to the media caused the European Union had to take steps to prevent this domination, inter alia by issuing a number of legal acts, co-production, creation of European works and various forms of state aid. The aim of the article is to prove that Europe has a long history of involvement in media and audiovisual policy, despite the strong position of the United States and its various activities include the creation and development of regulatory frameworks, creation of financing programs and even representation of European interests outside the European Union. In the article, the author refers to a number of books, articles, legal acts and research.

Key words: cinema, television, media, influence of the United States, European Union, legal acts, state aid, MEDIA programs, co-productions

Czym jest kino, film i telewizja? O ich wadze na przestrzeni lat i znaczeniu pisali w swojej książce Alicja Helman i Andrzej Pitrus. Czy czeka nas śmierć kina? Autorzy twierdzą, że „przez wszystkie dekady swego rozwoju kino zmieniało się bardzo szybko i dynamicznie, a wraz z nim zmieniali się również odbiorcy. (...) Nie 
zmieniło się tylko jedno - przeświadczenie o niezwykle doniosłej roli filmu w życiu każdej ludzkiej społeczności. W latach 30. Erwin Panofsky kontrowersyjnie zauważył, że gdyby zakazać wszelkiej działalności artystycznej, gdyby literaci przestali pisać, muzycy komponować, malarze tworzyć obrazy, nieliczni w ogóle dostrzegliby ten fakt, a jeszcze mniej liczni by tego żałowali. Gdyby jednak ten zakaz objął także film, skutki społeczne byłyby katastrofalne. Czy nam się podoba, czy nie, właśnie kino - wyraźniej niż jakikolwiek inny czynnik (...) kształtuje opinie, smak, język, ubiór, zachowanie i nawet fizyczny wygląd publiczności, obejmującej ponad 60\% mieszkańców Ziemi”' . To właśnie kino i telewizja w Europie będą przedmiotem zainteresowań tego artykułu, a dokładnie wpływ Stanów Zjednoczonych na ich rozwój i sposób przeciwdziałania tej dominacji.

Jeremie Tunstall na początku lat 80. twierdził, że „każde z funkcjonujących dziś mediów masowych zostało wynalezione w Stanach Zjednoczonych i tam uzyskało obecny kształt”2. Podkreślał on, że to właśnie media amerykańskie wpływają na większość mediów na świecie, podczas gdy Europa nie może się pochwalić takimi osiągnięciami na skalę światową. Czy Europa jest więc tylko dochodowym rynkiem dla amerykańskich koncernów? Wydaje się jednak, że media w Europie są strukturą odrębną, żyjącą własnym życiem i starającą się sprostać dominacji amerykańskiej.

Wzrost znaczenia Stanów Zjednoczonych w stosunku do mediów sprawił, że Unia Europejska musiała podjąć kroki w celu zapobieżenia tej dominacji, między innymi poprzez wydanie wielu aktów prawnych, powstanie koprodukcji, tworzenie utworów europejskich i różne formy pomocy państwa.

\section{Akty prawne}

Akty prawne stanowiły próbę przeciwdziałania nadmiernej amerykanizacji mediów. Jednym z takich pierwszych przykładów był raport Hahna z 1982 roku, który zaznaczał, że cały system telewizji europejskiej będzie ulegał zmianom, na przykład umiędzynarodowieniu. Przedstawił on potencjalne zagrożenia związane ze zmianami, które zachodziły w Europie, takie jak między innymi pojawienie się zjawiska „kolonizacji cywilizacyjnej” państw słabszych przez większe i o większym potencjale produkcyjnym i nadawczym, drastyczne obniżenie przez kanały komercyjne poziomu programów emitowanych do odbiorców czy też „gwałtowna i niepohamowana inwazja produkcji amerykańskiej”3.

1 A. Helman, A. Pitrus, Podstawy wiedzy o filmie, Słowo/Obraz Terytoria, Gdańsk 2008, s. 5.

2 J. Tunstall, The Media Are American, Constable, London 1977, w: K. Williams, Media w Europie, Wydawnictwa Akademickie i Profesjonalne, Warszawa 2008, s. 12.

3 P.J. Humphreys, Mass Media and Media Policy in Western Europe, Manchester University Press, Manchester 1996, s. 259, w: M.K. Szewczyk, Polityka audiowizualna Unii Europejskiej, www. uw.lodz.pl, s. 171. 
Kolejnym dokumentem była uchwała De Vriesa z 1985 roku, w której wykazano, że powinny istnieć zachęty dla europejskiej produkcji programowej i przepisy gwarantujące obecność treści europejskich w zawartości programów telewizyjnych ${ }^{4}$.

W 1990 roku Komisja Europejska opublikowała pierwszy komunikat dotyczący polityki audiowizualnej. Wymienione zostały w nim podstawowe wytyczne polityczne, jak między innymi wzmocnienie europejskiego rynku audiowizualnego w celu uczynienia go bardziej konkurencyjnym w skali światowej, stworzenie warunków swobodnego przepływu programów oraz działania w szerszej skali niż dotychczas w celu rozciągnięcia europejskiej przestrzeni audiowizualnej na inne kraje europejskie ${ }^{5}$. Warto zaznaczyć, że dokument ów zawierał również informację o urugwajskiej rundzie negocjacji w ramach GATT, co było kolejnym dowodem na umiędzynarodowienie działalności Europejskiej Wspólnoty Gospodarczej w dziedzinie mediów.

W dyrektywie „Telewizja bez granic” z 1997 roku zachowano natomiast rozdział trzeci, który określał minimalny udział europejskich programów w całej ramówce. Punkt ten bezpośrednio godził $\mathrm{w}$ interesy nadawców amerykańskich, którzy emitowali swój program w Europie. Był on szeroko dyskutowany przed umieszczeniem go w nowej dyrektywie, jako że zmuszał nadawców amerykańskich do współpracy z europejskimi producentami. Wcześniej głównie opierali się oni jedynie na własnym repertuarze. Głosy sprzeciwu podnosiły również państwa członkowskie i europejscy nadawcy z powodu konieczności zakupu drogich produkcji europejskich zamiast tańszych utworów zza oceanu ${ }^{6}$. I tak najnowsza nowelizacja dyrektywy podkreśliła, że nadawcy są zobowiązani do przeznaczania przynajmniej $10 \%$ czasu antenowego lub $10 \%$ budżetu programowego na utwory europejskie wyprodukowane przez producentów niezależnych od nadawców, z wyłączeniem czasu przeznaczonego na nadawanie: programów informacyjnych, wydarzeń sportowych, gier, reklamy, usług teletekstu, telezakupów ${ }^{7}$.

Co więcej, działania podejmowano także w Polsce. Ustawa o radiofonii i telewizji ustaliła kwotę niezależnych producentów europejskich na 10\%. Wskazywała ona, że przynajmniej 50\% z nich powinny stanowić audycje wytworzone do pięciu

${ }^{4}$ European Parliament, Report on a framework for a European media policy based on the Commission's Green Paper on the establishment of the common market for broadcasting, especially by satellite and cable, COM (84) 300 final, Brussels 1985; European Parliament, Report drawn up on the economic aspects of the common market for broadcasting, COM (84) final, Brussels 1985, w: K. Jakubowicz, Unia Europejska a media. Między kultura a gospodarka, Wydawnictwa Akademickie i Profesjonalne, Warszawa 2010, s. 38-39.

${ }^{5}$ European Commission, The European Community Policy in the Audiovisual Field. Legal and political texts, COM (90) 78, Brussels 1990; European Commission, Communication on audiovisual policy, COM (90) 78 final, Brussels 1990, w: K. Jakubowicz, op. cit., s. 47.

${ }_{6}^{6}$ M.K. Szewczyk, Polityka audiowizualna - Unia Europejska - Polska, wybrane zagadnienia, 2002, http://www.europedirect-katowice.pl, s. 57-60.

7 Źródło: http://europa.eu. 
lat przed rozpowszechnieniem. Dodatkowo ustawa ograniczyła możliwość udziału pozaunijnego zagranicznego kapitału w kapitale zakładowym spółki do 49\%

Podobnie tworzono akty prawne $\mathrm{w}$ innych krajach, jak na przykład w Wielkiej Brytanii. W 1951 roku opublikowano tam „Beveridge Report”. Był on odpowiedzią na zwiększającą się dominację amerykańską i dotyczył zasadniczych zmian w ramach BBC. W 1954 roku rząd przyjął „Television Act” otwierający ograniczone możliwości powstania stacji komercyjnych. Co ciekawe, zniesienie monopolu BBC miało wbrew pozorom zagwarantować nieobniżenie standardów oraz chronić przed nadużyciami. I tak dzięki temu w 1956 roku mogła powstać ITV (Independent Television), czyli pierwsza europejska telewizja komercyjna. Jednak nawet będąc telewizją komercyjną, musiała wypełniać pewne elementarne zobowiązania należące do zakresu działań służby publicznej ${ }^{9}$.

Jednakże próba promowania kina europejskiego uwidoczniła się przede wszystkim w prowadzonych na początku lat 90 . negocjacjach dotyczących odnowienia „Układu Ogólnego w sprawie Taryf Celnych i Handlu” („General Agreement on Tariffs and Trade" - GATT). Miały one na celu ułatwienie wolnego przepływu towarów między państwami. GATT miał służyć jako forum negocjacji w sprawie zmian taryf celnych. Runda urugwajska, czyli ósme i ostatnie spotkanie w celu zmiany ceł, odbywała się w latach 1986-1993, kiedy to udało się uzyskać porozumienie między Stanami Zjednoczonymi a Europą. Te pierwsze początkowo żądały, by europejski rynek filmowy i telewizyjny został otwarty na nieograniczony przepływ dóbr, jednakże Unia Europejska próbowała się temu sprzeciwić. W rezultacie wprowadzono system kwot i restrykcji, aby chronić branżę filmową. Unii Europejskiej udało się wywalczyć wyjątek dla kultury. Należy jednak pamiętać, że od powstania w 1995 roku Światowa Organizacja Handlu (WTO) coraz agresywniej dąży do wprowadzenia zasad wolnorynkowych w branży audiowizualnej ${ }^{10}$.

W kolejnych latach kontynuowano tradycję wydawania aktów prawnych związanych z sektorem medialnym. W 1993 roku powołany został „Think-Tank on the Audiovisual Policy of the European Union". Jego zadaniem było przedstawienie stanu rzeczy w rzeczywistości post-GATT-owskiej ${ }^{11}$. W ciągu 15 lat udział produkcji amerykańskich w repertuarze kin wzrósł bowiem z 35\% do 80\%, podczas gdy filmy europejskie miały tylko $1 \%$ udziału w rynku amerykańskim ${ }^{12}$. Przemysł USA w stosunku do Europy wzrósł w okresie 10 lat z 330 milionów w 1984 roku do 3600 milionów w $1992 \mathrm{roku}^{13}$. Co więcej, w ciągu 10 lat filmy europejskie straciły około

${ }^{8}$ E. Stasiak-Jazukiewicz, M. Jas-Koziarkiewicz, Polityka medialna w Unii Europejskiej, Poltext, Warszawa 2011, s. 409.

${ }^{9}$ M.K. Szewczyk, op. cit., s. 15.

${ }^{10}$ K. Williams, op. cit., s. 107, 126; K. Jakubowicz, op. cit., s. 48.

${ }^{11}$ K. Jakubowicz, op. cit., s. 48.

${ }_{12}$ Report by the Think-Tank on the Audiovisual Policy of the European Union, 1994, http://aei. pitt.edu/1593/1/av_think_tank_rept.pdf, w: K. Jakubowicz, op. cit., s. 48.

${ }^{13}$ Ibidem. 
50\% europejskiego rynku filmowego na rzecz przemysłu Stanów Zjednoczonych. W 1968 roku najbardziej kasowe amerykańskie filmy stanowiły w Europie 35\%, podczas gdy europejskie $60 \%$. W 1994 roku udział filmów amerykańskich w przemyśle w Unii Europejskiej wynosił już 80\%.

Wyjścia z zaistniałej sytuacji szukano już w 1994 roku na Europejskiej Konferencji Audiowizualnej w Brukseli, gdzie przedstawiono rekomendacje z raportu „Report by the Think-Tank on the Audiovisual Policy in the European Union”. Powołano się wtedy między innymi na Białą Księgę, która dotyczyła wzrostu, konkurencyjności i zatrudnienia („White Paper on growth, competitiveness, and employment - The challenges and ways forward into the 21 st century"). W tekście zauważono między innymi, że sektor audiowizualny, definiowany jako produkcja i dystrybucja programu oraz produkcja sprzętu, ma zarówno znaczenie kulturalne, jak i gospodarcze ${ }^{14}$.

W kolejnych latach produkcja Stanów Zjednoczonych była nadal silna. Według European Observatory w 2002 roku udział produkcji USA na rynkach 12 państw członkowskich Unii Europejskiej wynosił aż 70\%, natomiast w 2002 roku tylko 8\% filmów europejskich pokazywano w innych niż kraj producenta europejskich krajach $^{15}$. Także teraz dystrybucja filmowa w Europie zdominowana jest przez Amerykanów ${ }^{16}$.

\section{Koprodukcje i utwory europejskie}

Jednym ze sposobów przeciwdziałania nadmiernej amerykanizacji kina w Europie jest omawiana już wcześniej współpraca. Rezultatem restrukturyzacji systemu finansowania były pojawiające się na coraz większą skalę koprodukcje. Uważano, że ściślejsza współpraca może odgrywać ważną rolę we wzmocnieniu konkurencyjności i ochrony europejskiego prawa audiowizualnego na poziomie międzynarodowym ${ }^{17}$. Przykładowo, PolyGram Filmed Entertainment (PEE), własność międzynarodowego koncernu Philips, zebrał grupę spółek zależnych i wyprodukował wiele znanych filmów. Przedsięwzięcie miało na celu zbudowanie silnej europejskiej przeciwwagi dla Hollywood ${ }^{18}$. Także w tym wypadku nie udało się osiągnąć celu.

${ }_{14}$ Proceedings of the European Audiovisual Conference, 1995, Brussels, Luxembourg, za: White Paper on growth, competitiveness, and employment - The challenges and ways forward into the 21st century, http://europa.eu, w: K. Jakubowicz, op. cit., s. 49.

${ }_{15}$ European Audiovisual Observatory, World Film Market Trends, Strasbourg 2003, w: K. Williams, op. cit., s. 110, 123.

16 J. Wasko, Hollywood in the Information Age, Polity Press, London 1994, s. 222, w: K. Williams, op. cit., s. 123.

${ }^{17}$ European Commission, Commission Staff Working Document on the External Dimension of Audiovisual Policy, SEC(2009), 1033, w: P. Valcke, K. Lefever, Media Law in the European Union, Wolters Kluwer, The Netherlands 2012, s. 125.

${ }^{18}$ J. Tunstall, D. Machin, The Anglo-American Media Connection, 1999, s. 138, w: K. Williams, op. cit., s. 123. 
Kiedy w latach 20. w Europie pojawiła się produkcja amerykańska, twórcy postanowili współpracować. I tak przedstawiciele niemieckiej kinematografii opowiadali się za współpracą na europejską skalę, aby przełamać niechęć do Niemiec, jaka powstała podczas wojny. Erich Pommer, prezes UFA, czyli holdingu kontrolującego większość niemieckiego przemysłu filmowego, wezwał do „produkcji filmów, które nie byłyby już francuskie, angielskie, włoskie czy niemieckie, lecz europejskie”, i które „można by pokazywać w całej Europie, dzięki czemu zwracałyby się koszty produkcji”' ${ }^{19}$. W rezultacie UFA podpisała z firmami brytyjskimi, francuskimi i rosyjskimi wiele umów dotyczących dystrybucji filmów produkowanych przez partnerów. $\mathrm{Z}$ czasem także niemiecka kinematografia inwestowała w koprodukcje i wchodziła w spółki z kinematografiami innych państw. W 1935 roku próbowała nawet doprowadzić do powstania międzynarodowego koncernu, który mógłby być zagrożeniem dla Hollywood ${ }^{20}$.

W kolejnych latach po wojnie pojawiła się idea stworzenia ogólnoeuropejskiego kina. Organy Unii Zachodnioeuropejskiej odpowiedzialne za kulturę powołały podkomitet do spraw propagowania współpracy i produkcji filmów promujących wspólne dziedzictwo Europy, natomiast Rada Europy utworzyła komitet mający na celu zbliżenie europejskich filmowców ${ }^{21}$. Wysiłki te zastąpiono w latach 90., kiedy to w 1989 roku Komisja Europejska powołała program MEDIA (Measures to Encourage the Development of the Audio-visual Industry), zaś w 1988 roku rozpoczęto projekt EURIMAGES, w ramach którego stworzono fundusz wspierający koprodukcje filmów fabularnych i dokumentalnych. W rezultacie w latach 90. nasiliła się także współpraca dwustronna i wielostronna między europejskimi krajami, a poszukiwanie partnerów do produkcji było koniecznością. Dlatego też współpraca stała się normą we współczesnym kinie europejskim. Waga umów o współpracy stała się widoczna tuż po wojnie. Francja i Włochy podpisały porozumienie już w 1949 roku. Dzięki niemu do lat 90. powstało ponad 1,5 tysiąca filmów. I tak Francja podpisała umowy o współpracę aż z 40 krajami, nie tylko z Europy. To ona również odegrała największą rolę przy powstaniu EURIMAGES oraz MEDIA ${ }^{22}$. Co prawda Wielka Brytania dołączyła do programu EURIMAGES w 1993 roku, ale już dwa lata później wycofała się z niego. Na drodze do współpracy francusko-brytyjskiej stanęły więc przeszkody kulturowe i językowe. Należy jednak pamiętać, że prawdziwą przyczyną niezgody między krajami były różnice zdań co do polityki wobec kinematografii. Francja kładła nacisk na zachowanie kultury i tożsamości narodowej między innymi poprzez wysoko rozwinięty

19 J. Forbes, S. Street, European Cinema: An Introduction, Palgrave, Basingstoke 2000, s. 9, w: K. Williams, op. cit., s. 119.

${ }^{20}$ K. Williams, op. cit., s. 119.

${ }^{21}$ P. Hainsworth, Politics, culture and cinerama in the New Europe, w: J. Hill, M. McLoone, P. Hainsworth (red.), Border Crossings: Film in Ireland, Britain and Europe, BFI, London 1994, s. 1314, za: K. Williams, op. cit., s. 120.

${ }^{22}$ K. Williams, op. cit., s. 120-121. 
system subsydiów, zaś Wielka Brytania opierała się na leseferyzmie i widziała w kinie jedną z gałęzi gospodarki ${ }^{23}$.

Próba stworzenia paneuropejskiej telewizji i kina wiązała się także z wyzwaniami. Takim wyzwaniem były siły dążące do decentralizacji polityki oraz społeczeństwa europejskiego. W latach 70. i 80. przeprowadzono w Europie wiele kampanii na rzecz zwiększania dostępu poszczególnych grup mniejszościowych mediów i zapewnienia im reprezentacji. Zaczęła się wtedy dynamicznie rozwijać telewizja regionalna ${ }^{24}$.

Kolejnym wyzwaniem były różnice w specyfice rynków krajowych Unii Europejskiej, napięcia wewnętrzne, różne interesy oraz rozbieżności między ekonomicznymi a kulturalnymi celami polityki medialnej w krajach Unii. Mimo że wzmocniła się współpraca wielostronna i dwustronna, znamienne były różnice pomiędzy poszczególnymi państwami ${ }^{25}$. Wydaje się więc, że tendencje decentralistyczne oraz podkreślające różnice w specyfice rynków krajowych Unii paradoksalnie osłabiły rynek medialny.

\section{Pomoc państwa i programy MEDIA}

Kolejną z form przeciwdziałania amerykanizacji jest regularna interwencja na rynku filmowym. Szacuje się, że państwa członkowskie wydają około 3 miliardów euro rocznie na wspomaganie europejskiego przemysłu filmowego. $Z$ tego około $80 \%$ przeznaczonych jest na produkcję filmową ${ }^{26}$. Mieszkańcy Europy w przeszłości stosowali wiele subsydiów, limitów, podatków, zwolnień od podatków umów handlowych i ograniczeń, aby sfinansować i wspierać rodzimą produkcję filmów. Ochrona taka zapoczątkowana została w Niemczech w 1921 roku. Wprowadzono wtedy ograniczenia w imporcie filmów z zagranicy ${ }^{27}$. Limity wprowadzono też w Wielkiej Brytanii, Francji i we Włoszech. W Wielkiej Brytanii cło Daltona z 1947 roku, Narodowa Korporacja Finansowania Filmów (National Film Finance Corporation NFFC) oraz podatek Levy’ego były głównymi przejawami starań rządu, by sfinansować odbudowę krajowego przemysłu filmowego ${ }^{28}$. Natomiast we Francji w 1946 roku

23 A. Jackel, Broadcasters' involvement in cinamatographic co-productions, w: M. Scriven, M. Lecomte (red.), Television Broadcasting in Contemporary France and Britain, Berghan Books, Oxford 1999, s. 177, za: K. Williams, op. cit., s. 121.

${ }^{24}$ R. Dudrah, Zee TV-Europe and the construction of pan-European South Asian identity, 2002, w: K. Williams, op. cit., s. 26.

25 K. Williams, op. cit., s. 121.

26 The European Union: A Guide for Audiovisual Professionals, February 2013, www.mediadeskuk.eu.

27 J. Forbes, S. Street, op. cit., s. 7, w: K. Williams, op. cit., s. 112.

28 M. Dickinson, S. Street, Cinema and State: The Film Industry and the British Government 1927-84, BFI, London 1985, w: K. Williams, op. cit., s. 112. 
powstało Narodowe Centrum Kinematografii (Centre Nationale de la Cinématographie - CNC) po to, by czuwać nad finansowaniem rodzimych filmów. Środki pochodziły ze specjalnego funduszu, Compte de soutien, pobierającego podatek od przychodów kin oraz od 1984 roku podatek od zysków firm telewizyjnych ${ }^{29}$. Co więcej, w którymkolwiek państwie Europy szukać, znajdziemy ciało powołane do promocji krajowej produkcji filmowej.

Reasumując, gdy mowa o pomocy państwa, chodzi o dwa rozwiązania: można zakazać nadawcom publicznym emisji reklam i w całości finansować je z opłat abonamentowych oraz budżetu państwa, czego przykładem jest BBC, lub można zlikwidować opłaty abonamentowe i skazać telewizje publiczne na prawie stuprocentowe samofinansowanie $\mathrm{z}$ reklam, co z kolei praktykowane jest w Hiszpanii i Portugalii ${ }^{30}$. Trzeba zaznaczyć, że pierwszy scenariusz jest dominujący.

W 2009 roku Komisja Europejska ogłosiła, że unijni nadawcy publiczni łącznie otrzymują ponad 22 miliardy euro w formie opłat abonamentowych lub bezpośredniej pomocy państwa. Czyni ich to trzecim beneficjentem pomocy publicznej, za sektorem rolnictwa i transportu ${ }^{31}$.

Warto również podkreślić, że pomoc państwa obejmuje nie tylko świadczenia pozytywne, jak na przykład subwencje, ale także działania zmniejszające obciążenia zazwyczaj nakładane na przedsiębiorstwa, takie jak zwolnienia z podatków. Natomiast rekompensata kosztów wykonywania misji publicznej nie należy do pomocy publicznej.

W komunikacie Komisji w sprawie stosowania zasad pomocy państwa wobec radiofonii i telewizji publicznej z 2001 roku wymieniono warunki, jakie musi spełnić pomoc, by zostać uznana za pomoc publiczną państwa. Są to kolejno: interwencja ze strony państwa lub za pomocą państwowych zasobów, wpływ interwencji na handel pomiędzy państwami członkowskimi, przynoszenie poprzez pomoc korzyści beneficjentowi, a także brak zakłócenia bądź groźby zakłócenia konkurencji. Wystąpienie pomocy państwa należy ponadto ocenić w sposób obiektywny przy uwzględnieniu orzecznictwa sądów Unii Europejskiej.

Jedną z form pomocy państwa są programy MEDIA. Potrzeba ich powołania uwidoczniła się już w latach 80 . Wtedy, w ciągu dziewięciu lat, ogólna produkcja filmowa zmalała w Europie o więcej niż 40\%. Dodatkowo ponad 80\% audiowizualnej produkcji europejskiej z 1990 roku nie zostało rozdystrybuowane poza granice państwa, w którym powstało ${ }^{32}$. Dlatego Komisja Europejska już w pierwszej połowie lat 80. przedstawiła pomysł stworzenia funduszu na rzecz finansowania koprodukcji. W 1985 roku Rada Unii Europejskiej odrzuciła tę propozycję, natomiast późniejsze propozycje wspierania samej produkcji audiowizualnej czy koprodukcji spotkały się

29 S. Hayward, French National Cinema, Routledge, London 1993, s. 46, w: K. Williams, op. cit., s. 112.

${ }^{30}$ M.K. Szewczyk, op. cit., s. 30-33.

${ }^{31}$ K. Jakubowicz, op. cit., s. 134-135.

32 M.K. Szewczyk, op. cit., s. 83. 
ze sprzeciwem państw członkowskich. Należy jednak pamiętać, że jednocześnie wykluczono bezpośrednią pomoc finansową dla samej produkcji audiowizualnej oraz istnienie jednego wspólnego funduszu wspierania sektora audiowizualnego ${ }^{33}$.

Tak naprawdę prawdziwe zmiany zaszły dopiero w grudniu 1990 roku, kiedy to Rada Unii Europejskiej do spraw Kultury podjęła decyzję nr 90/685/WE o uruchomieniu pięcioletniego programu MEDIA I działającego w latach 1991-1995. Na program MEDIA I przeznaczono zaledwie 50 milionów ECU rocznie. Miał on realizować następujące cele ogólne: tworzyć jednolity rynek wspólnotowy dla usług audiowizualnych, promować współpracę między profesjonalistami, którzy mieli sami kształtować inicjatywy realizowane w ramach programu i je nadzorować, promować małe i średnie przedsiębiorstwa oraz stwarzać bodźce szczególnie dla tych, które działają w krajach o „mniej rozpowszechnionych” językach i kulturach, tworzyć samowystarczalne i samofinansujące się projekty audiowizualne, w których udział środków wspólnotowych nie przekraczałby $50 \%{ }^{34}$. Główną domeną funkcjonowania tego programu było stworzenie aż 19 specjalistycznych podprogramów i zapewnienie warunków realizacji wskazanych w nim celów ${ }^{35}$.

Jak oceniono efekty programu? Z danych Eurostatu wynika, że w ciągu czterech lat (1991-1994) liczba sal kinowych w Unii wzrosła o ponad pół tysiąca, czyli o ponad 3\% stanu z 1991 roku, i niemalże dorównała wysokim danym z 1988 roku. Co więcej, wzrosła również liczba europejskich produkcji filmowych, w taki sposób, że w roku 1996 europejska produkcja kinowa osiągnęła ogólną liczbę 610 filmów pełnometrażowych. Mimo że dane te pochodzą z późniejszych lat niż funkcjonowanie programu MEDIA, ich wyraźny wzrost jest związany z jego oddziaływaniem ${ }^{36}$.

Wielu uważa jednak, że dopiero MEDIA II miało poważny wpływ na kino i telewizję. Program ten został podzielony na dwie części i wszedł w życie 1 stycznia 1996 roku, operując budżetem wynoszącym aż 310 milionów ECU. Miał on dwa podstawowe cele: podniesienie konkurencyjności europejskiego przemysłu audiowizualnego oraz stworzenie warunków do rozwoju wszelkich działań w tej dziedzi$n^{3} \mathrm{e}^{37}$. W pierwszych latach funkcjonowania programu $\mathrm{z}$ jego funduszy dofinansowano aż 64 festiwale filmowe, na których pokazano 7500 wytworów europejskiej produkcji audiowizualnej. Co więcej, raport podsumowujący działalność programu MEDIA II ukazał, że w czasie jego trwania podwoiła się liczba filmów europejskich rozpowszechnianych poza krajem ich produkcji - z 246 w roku 1996 do 499 $\mathrm{w}$ roku $2000^{38}$. Ocenia się, że program MEDIA II miał poważny efekt mnożnikowy: każde euro wydane w ramach MEDIA II generowało 5,75 euro w inwestycjach

\footnotetext{
${ }^{33}$ K. Jakubowicz, op. cit., s. 165-166.

${ }^{34}$ Ibidem, s. 166.

${ }^{35}$ M.K. Szewczyk, op. cit., s. 83-84.

${ }^{36}$ Ibidem, s. 84-85.

37 Ibidem, s. 85-86.

${ }^{38}$ E. Stasiak-Jazukiewicz, Polityka medialna Unii Europejskiej, Wydawnictwo Sejmowe, War-
} szawa 2005, s. 102-104. 
krajowych, szczególnie w sektorze dystrybucji. Dysponując skromnymi środkami, program MEDIA II nie mógł samodzielnie przyczynić się do osiągnięcia tych rezultatów, niemniej efekt był znaczący ${ }^{39}$.

W latach 2001-2005 funkcjonował z kolei program MEDIA Plus. Miał on budżet sięgający 400 milionów euro i był kontynuacją programów MEDIA. Jego zasadniczym celem było ponownie umacnianie konkurencyjności europejskiego przemysłu audiowizualnego ${ }^{40}$. Równolegle z MEDIA Plus funkcjonował program MEDIA II Szkolenia. Decyzja o jego uruchomieniu została podjęta przez Radę i Parlament Europejski 19 stycznia 2001 roku. Programowi przyznano budżet w wysokości 50 milionów euro, który po decyzji o przedłużeniu obowiązywania programu do końca grudnia 2006 roku wzrósł do 59,4 miliona euro. Jego celem była poprawa szkolenia zawodowego osób zatrudnionych w sektorze audiowizualnym, co miało służyć poprawie konkurencyjności europejskiego przemysłu audiowizualnego. Podsumowanie wyników tych dwóch programów wskazuje, że w trakcie ich trwania wsparto łącznie 9000 projektów. Program prawdopodobnie przyczynił się do stałego wzrostu udziału filmów $\mathrm{z}$ innych krajów unijnych w ofercie kinowej nowych państw członkowskich - kosztem filmów amerykańskich, a nie krajowych ${ }^{41}$.

Natomiast program MEDIA 2007 posiadał budżet w wysokości 755 milionów euro i działał w latach 2007-2013. Zakładał, iż program MEDIA pomoże tworzyć sieci operatorów, powiększy udział europejskich filmów na rynku międzynarodowym z obecnych $11 \%$ do $20 \%$ w roku 2013 , umożliwi współpracę 40 europejskim akademiom filmowym, a także podwoi liczbę europejskich kampanii dystrybuujących produkcje telewizyjne i filmowe ${ }^{42}$.

Ważnym przedsięwzięciem był również program MEDIA INTERNATIONAL, któremu Parlament Europejski przyznał w 2007 roku budżet w wysokości 2 milionów euro. Środki przeznaczono na przygotowanie działań mających na celu wzmocnienie kooperacji między przemysłem audiowizualnym w krajach trzecich a krajami unijnymi. Budżet stopniowo zwiększono, dzięki czemu już w 2009 roku wyniósł on 5 milionów euro. Akcja ta miała swoją kontynuację w postaci programu MEDIA MUNDUS. Był to szeroki program współpracy międzynarodowej adresowany do branży audiowizualnej i mający na celu wzmocnienie kulturalnych i handlowych stosunków między kinematografią europejską a filmowcami z krajów trzecich. W ramach MEDIA MUNDUS w latach 2011-2013 przeznaczono aż 15 milionów euro na projekty przedstawiane przez twórców audiowizualnych z Unii i krajów trzecich ${ }^{43}$. Dodatkowo powstała akcja MEDIA International Preparatory Action, której budżet w latach 2008-2010 wyniósł 8 milionów euro. Podobnie jak

\footnotetext{
${ }^{39}$ K. Jakubowicz, op. cit., s. 168-169.

${ }^{40}$ M.K. Szewczyk, op. cit., s. 92-95.

${ }^{41}$ K. Jakubowicz, op. cit., s. 170-171.

${ }^{42}$ E. Stasiak-Jazukiewicz, op. cit., s. 107-108.

${ }^{43}$ K. Jakubowicz, op. cit., s. 222-223.
} 
MEDIA MUNDUS została ona utworzona w celu wzmocnienia współpracy między Europą i krajami trzecimi ${ }^{44}$.

Na koniec należałoby zadać pytanie, czy programy MEDIA całkowicie spełniły swoją rolę? Wydaje się, że odpowiedź nie jest pozytywna, o czym świadczą badania przeprowadzone przez Europejskie Obserwatorium Audiowizualne w 2000 roku. Według nich, mimo że w Europie wyprodukowano 739 filmów, a w Stanach Zjednoczonych 628, wyświetlane w kinach europejskich filmy w 2000 roku to w $66 \%$ produkcja amerykańska, podczas gdy udział filmów europejskich na rynku amerykańskim to zaledwie $4,51 \%{ }^{45}$. Nie można jednak zaprzeczyć temu, że program MEDIA z całą pewnością poprawił dystrybucję filmów europejskich na terenie Europy.

Sama Unia Europejska nadal podejmuje działania w celu poprawy zaistniałej sytuacji. Komisja wydała między innymi Culture Progamme, którego budżet w latach 2007-2013 wyniósł 400 milionów euro. Wspomagał on projekty i inicjatywy służące kulturalnej różnorodności Europy i wspierał dziedzictwo kulturalne poprzez rozwój kooperacji między państwami i instytucjami. Natomiast w grudniu 2011 roku Komisja zaproponowała kolejny program o nazwie Creative Europe z proponowanym budżetem 1,8 miliarda euro na lata $2014-2020^{46}$.

\section{O mediach na zakończenie}

Historia mediów na świecie to historia wzajemnych powiązań mediów amerykańskich i europejskich. Nie jest możliwe omawianie poszczególnych systemów samoistnie, gdyż struktury te się przenikają.

Należy pamiętać, że media są wciąż najszybciej rozrastającym się sektorem gospodarki europejskiej i tworzą pokaźną liczbę miejsc pracy. W 2001 roku w przemyśle multimedialnym 15 państw członkowskich Unii Europejskiej funkcjonowało aż 1,5 miliona osób ${ }^{47}$.

Warto jeszcze raz podkreślić, że Europa posiada długą historię zaangażowania w politykę medialną i audiowizualną. Do jej różnorodnych działań można zaliczyć między innymi stworzenie ram regulacyjnych, utworzenie programów finansowania, czy choćby reprezentowanie europejskich interesów poza Unią (na przykład w Światowej Organizacji Handlu). Także kształtowanie się ram legislacyjnych było przedsięwzięciem bardzo długim i żmudnym, a wszystko wskazuje na to, że działania te będą kontynuowane, choćby ze względu na zmieniający się rynek mediów i postęp technologiczny.

${ }^{44}$ Project supported by the International Fund for Cultural Diversity: Measuring the Economic Contribution of the Audiovisual Industry in the Republic of Macedonia, http://www.vs.edu.mk.

${ }^{45}$ E. Stasiak-Jazukiewicz, op. cit., s. 102-104.

46 The European Union: A Guide for Audiovisual Professionals February 2013, www.mediadeskuk.eu.

${ }^{47}$ Exploration and development of the job potential in the cultural sector in the age of digitalization, 2001, MKW - raport końcowy, w: E. Stasiak-Jazukiewicz, op. cit., s. 31. 


\section{Bibliografia}

Attentional, Ramboll Management, Oliver \& Ohlbaum Associated, Headway International 2009, http://ec.europa.eu/avpolicy/docs/library/studies/art4_5/final_report.pdf, w: K. Jakubowicz, Unia Europejska a media. Między kulturq a gospodarka, Wydawnictwa Akademickie i Profesjonalne, Warszawa 2010.

Dickinson M., Street S., Cinema and State: The Film Industry and the British Government 1927-84, BFI, London 1985, w: K. Williams, Media w Europie, Wydawnictwa Akademickie i Profesjonalne, Warszawa 2008.

Dudrah R., Zee TV-Europe and the construction of pan-European South Asian identity, 2002, w: K. Williams, Media w Europie, Wydawnictwa Akademickie i Profesjonalne, Warszawa 2005.

European Audiovisual Observatory, World Film Market Trends, Strasbourg 2003, w: K. Williams, Media w Europie, Wydawnictwa Akademickie i Profesjonalne, Warszawa 2008.

European Commission, Commission Staff Working Document on the External Dimension of Audiovisual Policy, SEC(2009), 1033, w: P. Valcke, K. Lefever, Media Law in the European Union, Wolters Kluwer, The Netherlands 2012.

European Commission, The European Community Policy in the Audiovisual Field. Legal and political texts. COM (90) 78, Brussels 1990 oraz European Commission, Communication on audiovisual policy. COM (90) 78 final, Brussels 1990, w: K. Jakubowicz, Unia Europejska a media. Między kultura a gospodarka, Wydawnictwa Akademickie i Profesjonalne, Warszawa 2010.

European Parliament, Report on a framework for a European media policy based on the Commission's Green Paper on the establishment of the common market for broadcasting, especially by satellite and cable, COM (84) 300 final, Brussels 1985 oraz European Parliament, Report drawn up on the economic aspects of the common market for broadcasting, COM (84) final, Brussels 1985, w: K. Jakubowicz, Unia Europejska a media. Między kultura a gospodarka, Wydawnictwa Akademickie i Profesjonalne, Warszawa 2010.

Exploration and development of the job potential in the cultural sector in the age of digitalization, 2001, MKW - raport końcowy, w: E. Stasiak-Jazukiewicz, Polityka medialna Unii Europejskiej, Wydawnictwo Sejmowe, Warszawa 2005.

Forbes J., Street S., European Cinema: An Introduction, Palgrave, Basingstoke 2000, w: K. Williams, Media w Europie, Wydawnictwa Akademickie i Profesjonalne, Warszawa 2008.

Hainsworth P., Politics, culture and cinerama in the New Europe, w: J. Hill, M. McLoone, P. Hainsworth (red.), Border Crossings: Film in Ireland, Britain and Europe, BFI, London 1994, za: K. Williams, Media $w$ Europie, Wydawnictwa Akademickie i Profesjonalne, Warszawa 2008.

Hayward S., French National Cinema, Routledge, London 1993, w: K. Williams, Media w Europie, Wydawnictwa Akademickie i Profesjonalne, Warszawa 2008.

Helman A., Pitrus A., Podstawy wiedzy o filmie, Słowo/Obraz Terytoria, Gdańsk 2008.

Humphreys P.J., Mass Media and Media Policy in Western Europe, Manchester University Press, Manchester 1996, w: M.K. Szewczyk, Polityka audiowizualna Unii Europejskiej, www. uw.lodz.pl.

Jackel A., Broadcasters' involvement in cinamatographic co-productions, w: M. Scriven, M. Lecomte (red.), Television Broadcasting in Contemporary France and Britain, Berghan Books, Oxford 1999, za: K. Williams, Media w Europie, Wydawnictwa Akademickie i Profesjonalne, Warszawa 2008.

Jakubowicz K., Unia Europejska a media. Między kultura a gospodarką, Wydawnictwa Akademickie i Profesjonalne, Warszawa 2010. 
Proceedings of the European Audiovisual Conference, 1995, Brussels, Luxembourg, za: White Paper on growth, competitiveness, and employment - The challenges and ways forward into the 21st century, http://europa.eu.

Project supported by the International Fund for Cultural Diversity: Measuring the Economic Contribution of the Audiovisual Industry in the Republic of Macedonia, http://www.vs.edu.mk. Report by the Think-Tank on the Audiovisual Policy of the European Union, 1994, http://aei.pitt. edu/1593/1/av_think_tank_rept.pdf, w: K. Jakubowicz, Unia Europejska a media. Między kulturą a gospodarka, Wydawnictwa Akademickie i Profesjonalne, Warszawa 2010.

Stasiak-Jazukiewicz E., Jas-Koziarkiewicz M., Polityka medialna w Unii Europejskiej, Poltext, Warszawa 2011.

Stasiak-Jazukiewicz E., Polityka medialna Unii Europejskiej, Wydawnictwo Sejmowe, Warszawa 2005.

Szewczyk M.K., Polityka audiowizualna, Unia Europejska - Polska, 2002, http://www.europedirect-katowice.pl.

The European Union: A Guide for Audiovisual Professionals, February 2013, www.mediadeskuk.eu.

Tunstall J., Machin D., The Anglo-American Media Connection, 1999, w: K. Williams, Media w Europie, Wydawnictwa Akademickie i Profesjonalne, Warszawa 2008.

Tunstall J., The Media Are American, Constable, London 1977, w: K. Williams, Media w Europie, Wydawnictwa Akademickie i Profesjonalne, Warszawa 2008.

Wasko J., Hollywood in the Information Age, Polity Press, London 1994, w: K. Williams, Media w Europie, Wydawnictwa Akademickie i Profesjonalne, Warszawa 2008.

Williams K., Media w Europie, Wydawnictwa Akademickie i Profesjonalne, Warszawa 2008. 